\title{
Balzac and the African Explorer: Cognitive Mapping of the faubourg Saint-Germain
}

\author{
Jennifer Yee
}

Abstract: A fresh reading of Balzac's La Duchesse de Langeais (1834) reveals that the geography of African exploration, and of Andalusia as a liminal space between Europe and Africa, are mapped onto the geography of Paris. The class boundaries that separate the aristocratic faubourg Saint-Germain from the rest of Paris make its conquest, in the synecdochic form of the Duchess's heart, as problematic as the exploration of central Africa from which the protagonist Montriveau has just returned. A spatial reading of this kind reveals the profound unity of Balzac's novella despite its three-part, a-chronological structure. This article argues for the crucial importance of travel writing in understanding this novella, which can be seen as a form of secondary travel writing. More specifically, it is argued that Balzac is responding directly to a travel narrative by René Caillié that was published in 1830. As a result new light can be shed on La Duchesse de Langeais by critical approaches to narratives of travel and exploration, notably Mary Louise Pratt's notions of the "contact zone" and the "anti-conquest" narrative. The latter is invaluable in understanding the figure of Montriveau, whose voyage is one of pathos, suffering and epistemological failure (he does not bring back the information that he sought), aspects that draw on Caillié's reallife experience. The novella can, more broadly, be read in the light of Fredric Jameson's concept of "cognitive mapping", with its suggestion of a cognitive or epistemological failure at the heart of the European project to reach a fully global world-view. Balzac's Comédie humaine, despite its vast geographical, social and historical mapping of the French system, is already shot through with awareness of the failure or incompletion of a mapping project that would extend to a global vision. 
In the first half of the nineteenth century travel writing was an increasingly dynamic genre with a growing readership, particularly in France. Balzac was one of the rare French novelists of the time who did not produce any travel narratives, unless one counts the spoof Voyage de Paris à Java of 1832 (Thompson 1). He did however incorporate travel writing, in the form of micro-narratives or short embedded tales, within his novels. These can be understood as a critique of travel writing as a genre (Déruelle 325,341 ), but they are also a form of secondary travel writing, by which I mean literature that appropriates or incorporates first-hand accounts of actual voyages. His was in any case a distinctly spatial imagination; one recalls his famous pronouncement in the "Avant-propos" to La Comédie humaine: "Mon ouvrage a sa géographie comme il a sa généalogie et ses familles...” (1: 18-19). This geography is of course focused on the opposition Paris-Province, ${ }^{1}$ but Balzac was fascinated by maps, and not only those of France. In "Z. Marcas," when the eponymous hero encourages his friends to go abroad, "Il étudia pour nous le globe politique et chercha le pays où les chances étaient à la fois les plus nombreuses et les plus favorables à la réussite de nos plans. Il nous marquait les points vers lesquels devaient tendre nos études" (8: 848). Here, the points on a map are used as a way of conceiving narrative trajectories. A form of mapping can provide a key to narrative trajectories elsewhere in Balzac's øeuvre as well, as has been brilliantly demonstrated by the work of Franco Moretti, a key inspiration for the present study.

This article will focus on the mapping of non-metropolitan geography, analysing the novella La Duchesse de Langeais in the light of some of the "geographical notations" (Said 69) by which Balzac points out towards the wider world and the spheres of France's potential imperial ambitions. It is of course no news that the novella mentions Africa: the decisive, and chronologically earlier, events of the second part of the novella begin when the hero, the ex- 
Napoleonic general Montriveau, has recently returned from a traumatic experience of exploration in Africa. Nevertheless, the importance of Africa to our understanding of $L a$ Duchesse de Langeais is not always acknowledged. ${ }^{2}$ I am going to make a two-pronged argument that will I hope clarify the place of Africa, and travel writing, in the novella. On the one hand I will be looking at how Montriveau's spatial experience of Africa maps over his spatial (and political) journey into the faubourg St-Germain. And on the other, I will suggest that Balzac is responding to one particular travel narrative that was very topical at the time he wrote the first version of La Duchesse. Both these angles of approach suggest that the intertext of travel writing should inform our reading of metropolitan fiction.

La Duchesse de Langeais has been read in autobiographical terms as an act of personal revenge against the Marquise de Castries, and politically as an account of the intellectually stultified Restoration aristocracy. Neither of these approaches should prevent us from considering some of the novella's sources to be in contemporary travel writing. Indeed, Balzac uses travel narratives in a way that has important implications for the political reading of the novella. Tom Conley has argued that early modern maps reflect the project of nation building and the new identities of peoples in the wake of the discovery of the New World. Similarly, Balzac's mapping project in La Duchesse de Langeais sets up a parallel between the uncharted territories of two worlds that are both old and new: ancient Africa and its deserts, as yet unmapped by European explorers; and the nostalgic, retrograde old aristocracy, "new" terrain for the bourgeois adventurer.

Between these two distinct geographical areas, Balzac's novella effects a superimposition that can be approached via Fredric Jameson's concept of "cognitive mapping." This refers first of all to the attempts by an individual subject to locate him or herself within a complex social organization understood spatially. At the same time, our local mental map — of a city, for example, or a class — is projected outwards into an inadequate 
("garbled") mental map of the emerging global system that we carry around in our heads. Because this new global totality is both geographic and economic, cognitive mapping extrapolates spatial to social analysis. Jameson sees our attempt at cognitive mapping as doomed in the absence of a true concept of global social totality. ${ }^{3} \mathrm{He}$ is not specifically discussing Balzac, indeed his discussion is of modernism, and I think the case of Balzac requires us to nuance this view in two ways. Firstly, Balzac's version of cognitive mapping offers an early model of a semi-totalizing worldview, which incorporates the vast metropolitan scope of the Comédie humaine and branches out much more tentatively towards the world beyond France. And secondly, in the specific case I am looking at here, Balzac is using cognitive mapping precisely in order to point out the flaw in this ambitious project and the apparent impossibility of establishing secure knowledge either of the vast stretches of the African interior, or of the tortuous ways of the aristocratic heart. The incorporation of other genres, such as travel writing, is actually a means for the emergent realist novel to question the basis of its own referential knowledge, as Jameson has much more recently argued, in The Antinomies of Realism.

Liminal geographies and the heart of Paris

In Pierre Citron's seminal study of Balzac's orientalism, the Africa of La Duchesse de Langeais was seen as part of Balzac's vague "Orient" and even, geography notwithstanding, part of his "rêve asiatique." "Balzac's own terminology does indeed include Africa, as well as parts of Spain, in the "Orient" (for example 5: 1031); but this does not necessarily mean that Montriveau's long voyage is not specifically situated in Africa. Elisabeth Gerwin's important article is one of the rare studies that attributes a significant role to Montriveau's African experiences. ${ }^{5}$ Others have emphasized the contrast of the open spaces of Africa with the closed spaces of the convent and the salon in which the Duchess remains cloistered. ${ }^{6}$ The 
novella's repeated theme of separation and barriers has also been a focus of study. ${ }^{7}$ In fact, in their different ways the desert crossing, the island, the convent and the salon all evoke liminal spaces. Indeed, understanding both the interior and the exterior spaces in terms of liminality and border-crossing can help us grasp the tightly-worked unity of the novella.

La Duchesse de Langeais has an a-chronological structure, like that of La Peau de chagrin. The first and last parts take place in a convent on an unnamed Spanish island off the coast of Andalusia, a "rocher à demi européen, africain à demi" (5: 906). The middle section recounts the earlier events which led to the Duchess locking herself up in the convent. From the outset, before being situated in relation to the African hinterland of Montriveau's desert crossing, the Paris of the central section is thus set between narrative framing episodes situated in the frontier-space of the island. The latter is a doubly a liminal space: between sea and land, it is also situated at the great Romantic frontier between Europe and North Africa, celebrated by Victor Hugo in his preface to Les Orientales, where one also finds a formula that Balzac echoes closely: "l'Espagne est à demi africaine.",

In Balzac's hands, Hugo's Romantic Andalusian border is mapped over the frontier between classes that separates the aristocratic faubourg Saint-Germain from the rest of Paris. Largely protected from the effects of the Revolution and the Napoleonic wars (5: 905), the island is even the site of a mini Restoration, a "petite Restauration insulaire" (5: 909), thanks to the arrival of General Montriveau in 1823. The achronological narrative-a narrative coquetry, like that of the Duchess herself (Baron, "La Duchesse" 13)—encourages the reader to see the parallels between the opening and closing sections set on the island, on the one hand, and the central Parisian section, on the other. If we read Balzac's novella as secondary travel writing, meanwhile, his focus on liminal spaces can be understood in the light of the growing critical corpus dedicated to narratives of travel and exploration. In particular, the term "contact zone" is used by Mary Louise Pratt to describe "the space of colonial 
encounters, the space in which peoples geographically and historically separated come into contact with each other and establish ongoing relations, usually involving conditions of coercion, radical inequality, and intractable conflict" (6). For the French Romantic imagination, Andalusia still evokes a cultural contact zone, and this liminal geography is mapped over the space of the aristocratic faubourg of the Restoration, into which members of other classes venture in conditions of "radical inequality, and intractable conflict." Geographical frontiers are projected over the shifting social landscape of Balzac's Paris, which is itself described in terms of spatial separation: there is an "espace mis entre une classe et toute une capitale" (5: 926), keeping the aristocracy away from the mud, noise and smells of the popular quarters (5: 924).

By 1833 Balzac himself had recently undergone a conversion to support the legitimist aristocracy, of which he nevertheless remained sharply critical, and La Duchesse de Langeais reflects this ambivalence. The novella was to be published under the title "Ne touchez pas à la hache" in the militantly legitimist journal L'Écho de la jeune France, but the second installment, which included a lot of political analysis, was not deemed acceptable, and publication was interrupted. ${ }^{9}$ Montriveau, although of aristocratic origins, is part of the exNapoleonic elite; moreover, the artillery in which he served had radical and liberal affiliations of which even Bonaparte was wary. The Duchess, on the other hand, is very much part of the old aristocracy whose failure to adapt is outlined in the long preamble on the faubourg Saint-Germain and its social and spatial isolationism. Although the Duchess's cold heart does in the end open up, Montriveau doesn't recognize it in time and the failure of the two to form a loving couple suggests the ultimate sterility of the Restoration.

A powerful political reading of the Duchess Antoinette de Langeais as (Marie)Antoinette, and the "hache" of the subtitle as the threat of revolutionary violence, is given by Natalie Buchet Rogers. The novella's original title, "Ne touchez pas à la hache," is indeed an 
oblique reference to the execution of King Charles I, suggesting the hidden danger that menaces the aristocratic Duchess. But the real threat for the aristocracy of the nineteenth century, according to Balzac's analysis here, as in Le Cabinet des antiques, is its sclerosis, its closed nature. Over several pages (5: 926-934) he argues that the aristocracy is "mortellement malade," "avieilli" (5: 930, 931); in contrast to the English Tories it has not proved itself able to integrate new energetic elements (such as Montriveau). But the axe that threatens the aristocracy also suggests that masculinity will turn against a woman who belittles it (5: 989). The kidnapping of the Duchess and her threatened branding transpose the threat of social and political violence into melodrama, with Montriveau's homosocial secret society, the Treize, being the politically conservative equivalent of the underground resistance of the Carbonari. Despite this narrative defusing of revolutionary threat, La Duchesse de Langeais is no exception to Jameson's argument that Balzac is a great historical novelist precisely because the action of his novels is always dated specifically, and situated implicitly in relation to the "axial event" of the Revolution; although there are no mob scenes in his work, it is Paris itself that figures "the collective totality" rather than the crowd (Jameson, Antinomies 27374). The Andalusian island might seem rather distant from Paris, but its geographical liminality is mapped onto the class "contact zone" of the Restoration elite.

Interpreting the liminal situation of the first and final parts of the novel in terms of the contact zone allows us to understand them in unison with the African narrative, the reported story of Montriveau's exploration. The vast and inhospitable desert shows us the almost impossible paths that lead into the heart of the Duchess, and that heart is a synecdoche for the faubourg St Germain itself. Traversing the desert successfully becomes an allegory for the possibility of breaking through the rigid morgue of Restoration aristocracy and potentially injecting it with new life through love. And if Montriveau can map the African hinterland, then Balzac can map the dark heart of the decadent aristocracy. 


\section{Africa and the vulnerable voyager}

This brings me to the second part of my double argument: that the micro-narrative of Montriveau's past voyage of exploration draws not on a vague orientalism, but specifically on one recent voyage of exploration. Montriveau's voyage begins in Egypt, but continues into the interior of Africa: "Montriveau s'embarqua dans le dessein d'explorer la HauteÉgypte et les parties inconnues de l'Afrique, les contrées du centre surtout, qui excitent aujourd'hui tant d'intérêt parmi les savants." (5: 942, my emphasis). The mention of Egypt, and a reminder of it in the Egyptian-style torch and bed in his bedroom later (5: 992), have encouraged many critics to situate Montriveau's African travels in relation to that country. ${ }^{10}$ The Napoleonic associations of Egypt, very much to the fore in the 1830s (the last volume of the Description de l'Égypte appeared in 1829), might distract us from the fact that it in Upper Egypt, to the South, that Montriveau begins his journey, whereas the Napoleonic battles took place in Lower Egypt. Even more important, his intention is primarily to explore the unknown parts of central Africa: one of his aims is to discover the source of the Nile which, it was still thought, might join up with the Niger, as Herodotus had suggested.

In fact, the exploration of the Sahara and the interior of Africa was a hot topic of discussion in the 1820 s. In 1824 the French Société de géographie offered a prize of 10,000 francs for the first European traveller to return alive from Timbuktu, the fabled city of the desert, one-time capital of the Saharan trade in gold, ivory and slaves. A Scot, Gordon Laing, reached Timbuktu in 1826 but was massacred, along with his servants. It was a Frenchman, René Caillié, who then reached Timbuktu in 1827-28 from the West coast of Africa, mostly on foot. Travelling with various groups along existing trade routes, without European companions and disguised as a Muslim, he managed to cross the desert and reach Tangiers (he died in France in 1838 of an illness contracted during his African travels). Caillié's 
travels were much discussed in Paris after his return, and he was crowned by the Société de géographie on 5 December 1828. Indeed, such was the impact of his account internationally that it inspired the theme of the University of Cambridge's annual poetry prize in 1829 : "Timbuktu." ${ }^{11}$ Caillié was not immediately lionized by Parisian society, because his was an unorthodox voyage, without official recognition, and he brought back little scientific documentation of his discoveries. Nevertheless, his account was eventually published in March 1830 as the Journal d'un voyage à Temboctou et à Jenné, dans l'Afrique centrale, précédé d'observations faites chez les Maures Braknas, les Nalous et autres peuples; pendant les années 1824, 1825, 1826, 1827, 1828 (in three volumes and an atlas). ${ }^{12}$ Balzac may or may not have read Caillié's account or even met him, but would almost certainly have heard his travels discussed between 1829 and March 1833, when he began the first version of $L a$ Duchesse. The probable influence of Caillié's travel writing, among others, is suggested by Rose Fortassier in her invaluable notes to the Pléiade edition (5: 761 and 946n1). ${ }^{13}$ The action of the novella occurs earlier, before Caillié's exploration, but Balzac avoids anachronism by making the geography of the interior suitably vague. He also shifts the direction of the voyage, which takes Montriveau from Upper Egypt to West Africa (Senegal) rather than following Caillié's trajectory from West Africa (Guinea) to Morocco.

The importance of René Caillié as one of the models for Montriveau lies elsewhere. Caillié's travel account is remarkable for the image it projects of the traveller not as a protoimperialist and intrepid explorer, but as vulnerable and dependent on the charity of individual devout Muslims who only half believe his invented story. For most of the journey he is impoverished, sick, hungry, thirsty, frightened or humiliated. Disguised as a Muslim whose aim is to reach Egypt and thence Mecca, he cannot be seen to take notes and has to conceal the few that he does take (on the course of rivers, on cities and cultures encountered, and on agricultural resources). The voyage takes him 545 days and although he does reach 
Timbuktu, the fabled heart of the desert, he arrives in the house of the French Vice-Consul in Tangiers in the state of an emaciated beggar. Compare Montriveau's experience: "Son expédition scientifique fut longue et malheureuse. Il avait recueilli des notes précieuses destinées à résoudre les problèmes géographiques ou industriels si ardemment cherchés, et il était parvenu, non sans avoir surmonté bien des obstacles, jusqu'au cœur de l'Afrique." When at last he reaches "la colonie française du Sénégal" his notes are lost and he is "demimort, en haillons" (5: 942). Montriveau returns to Paris in 1818 "ruiné, sans protecteurs," but at last has some recognition thanks to "ses rapports avec les principaux savants de Paris et quelques militaires instruits [qui] firent connaître et son mérite et ses aventures," giving him "cette célébrité passagère dont les salons de Paris sont si prodigues" (5: 943). Our first glimpse of him in the Parisian salons shows him to be "habituellement silencieux comme le sont tous les hommes timides" (5: 941), an outsider who is unaccustomed to love and to high society; he remains naïve and childlike in relation to the complex social codes and hypocrisies of this unfamiliar territory. Caillié, on his real-life arrival in 1828, was penniless until the scientific community took him up and campaigned for him to be given a pension. He lived in Paris for three years writing his book, entering briefly into Parisian social and scientific circles despite his own very humble provincial background and lack of education. When he receives his prize "[1]e Tout-Paris savant et mondain est là, et même 'plusieurs dames"”; after that, "Paris lui ouvre les portes de ses salons et de la reconnaissance." 14

Both Caillié's account and the micro-narrative of Montriveau's exploration give us examples of what Pratt has called the "anti-conquest" narrative. This is a representational strategy whereby the European explorer portrays himself as innocent and even vulnerable, while at the same time asserting European hegemony. Pratt sees this stance as reflecting the influence of the sentimental mode that was so important from the end of the eighteenth century on. ${ }^{15}$ Travel narratives in which the explorer is defined by intensely individual 
experience can thus be situated in the lineage of Rousseau. ${ }^{16}$ Although Caillie himself emphasizes his emotions less than his physical state, both his account and Montriveau's experiences are striking for the pathos of the traveller as a vulnerable and desperate figure. Montriveau's superficially macho role as a returned African hero, incongruous in the aristocratic salons of the faubourg St Germain, belies the real weakness of his position in both his Parisian and African explorations.

In one striking experience during his travels, Montriveau "tomba par trahison au pouvoir d'une tribu sauvage. Il fut dépouillé de tout, mis en esclavage et promené pendant deux années à travers les déserts, menacé de mort à tout moment et plus maltraité que ne l'est un animal dont s'amusent d'impitoyables enfants." (5: 942). The children of the tribe's sheik invent a game in which the aim is to throw horse bones so that they land on his head (5: 943). The source for this may be Caillié's account of a game played by a community of "Maures" in which the aim is to hit a pile of small flat bones by throwing stones from a great distance; he describes this (adult) game in the same paragraph as a children's game in which a circle of children humiliate, hit and push another child isolated in the middle (Caillié 1: 191). Balzac appears to have combined the two games, and made his explorer the butt of them rather than a mere observer. There are numerous other instances in Caillié's long voyage when the explorer is humiliated by those he encounters. ${ }^{17}$ The children's game Balzac recounts (given, it is implied, as one example among many) condenses these into a single, striking instance of humiliation that foreshadows Montriveau's subsequent humiliation by the Duchess.

The Duchess herself is particularly moved by the account of another of Montriveau's African experiences, when he has persuaded a guide to accompany him across the desert, against the latter's advice (5: 944). Travelling on foot, Montriveau is exhausted by the moving sand "qui semblait à chaque pas fuir sous lui," but he continues because his guide repeatedly tells him that the remaining distance is less than it really is, remaining apparently 
"impitoyable" and calm, "comme un vrai démon" (5: 945). At the very end "le Nubien le prit sur ses épaules, l'éleva de quelques pieds, et lui fit voir à une centaine de pas un lac entouré de verdure $[\ldots]$ son guide, ce géant d'intelligence et de courage, acheva son œuvre de dévouement en le portant à travers les sentiers chauds et polis à peine tracés sur le granit." (5: 946). This vivid image of Montriveau being carried across the desert by the mighty and intelligent Nubian may have a source in Caillé's account of being picked up and carried in the arms of a "Maure" when he is thrown from his camel; the man holds him tightly against his chest to help him recover, and places him back onto the camel when it has been caught (Caillié 3: 17). ${ }^{18}$ Montriveau's account might also remind us of those rather troubling engravings that show a white explorer wearing a colonial pith helmet being carried on the shoulders of a single, half naked "native." ${ }^{\prime 19}$ But there is a psychological dimension to his experience that is not apparent in such engravings: far from being heroically in command, he is in despair, and survives thanks to a childlike dependence on his companion. Balzac's image is so vivid as to appear almost emblematic. It is possible that the mighty Nubian represents part of Montriveau's split self, and that he will be loved by Antoinette only if he can combine the humble weakness of the explorer with the virile power of the stoic and lucid African. In any case, what is clear is that to reach the oasis the traveller must go through a process of infantilization and accept his vulnerability. He must also renounce his fury, and Montriveau does not in the end mark the Duchess with a red-hot branding iron, just as he did not take up the Nubian's dagger to kill him when deceived by him in the desert (5: 946).

Montriveau's agonizing desert passage, which he survives only thanks to the Nubian "géant d'intelligence et de courage," can thus be mapped onto his later Parisian experience. Crossing the African desert he is given courage by the thought that the oasis is within reach, but each time it proves to be further away. So too in the prolonged foreplay imposed on her lover by the Duchess, the destination that is apparently within reach is postponed again and 
again. Reaching the oasis, Montriveau sees on the one side 'l'enfer des sables, et de l'autre le paradis terrestre de la plus belle oasis qui fût en ces déserts" (5: 946); Fortassier suggests this passage may have its origins in Caillié's account of how an oasis appears between granite rocks (Caillié 3: 6, Balzac 5: 946n1). In the Parisian side of his journeys, meanwhile, the oasis is often glimpsed but never fully attained. Antoinette allows Montriveau momentary triumphs that appear to promise that he will ultimately gain sexual satisfaction, but they are swiftly withdrawn. Eventually she allows him to kneel before her in her boudoir and kiss the hem of her dress, then her feet and her knees, a process followed by further mysteries that cannot be revealed for the sake of the honour of the faubourg Saint-Germain, but which allow her to enjoy pleasures that are, apparently, permitted by the secret and "jésuitique" diktats of her confessor or her conscience (5: 978-79; on the confessor, 5: 968). Montriveau is convinced that this means the Duchess belongs to him at last, but in a discussion with his worldlier friend the Marquis de Ronquerolles he learns that this is still the Duchess's way of not giving herself. It is only with Ronquerolles, man-to-man, that he obtains the frank truth: “ces deux êtres se regardaient et se parlaient seuls au coin d'un mur, aussi loin des hommes qu'ils eussent pu l'être au milieu d'un désert. ${ }^{, 20}$ If the oasis in the heart of the Parisian desert is to open up its secrets, it will only be thanks to the support of other men, a homosocial elite that is far from the experience of the masses; Ronquerolles, of course, is one of the Treize.

Balzac portrays much of himself in Montriveau, who resembles him physically, with his wide, square face and solid build. He gave the explorer what he saw as his own energy and potential ability to revitalize the old aristocracy. That the author of La Comédie humaine may also have identified with René Caillié, with whom he shared his year of birth (1799) and his unruly dark locks, is only conjecture. But just as the bourgeois novelist gained insight into the aristocracy precisely because of his outsider status, so too the apparent weakness of the explorer was in fact what enabled his achievement. Caillé's position of weakness was a 
deliberate and strategic choice (admittedly no other was available to him, given his lack of financial means or backing). He contrasts his own approach with that of Gordon Laing, the details of whose death near Timbuktu in September 1826 he learned from local accounts on his own arrival in April 1828. Major Laing wore European clothes, told everyone he was sent by the King of England, repeatedly refused to acknowledge that Mahomet was the prophet of God, and openly drew up a map of Timbuktu; Caillié sees this behaviour as the cause of his death. ${ }^{21}$ It is only the lone traveller, weak and vulnerable, who is actually able to cross the desert, reach the forbidden city, and survive. ${ }^{22}$

Caillié's account is remarkable for the split nature of the explorer's role (Pratt's “anticonquest" narrative): the explorer is vulnerable, apparently harmless and solitary, but as well as observing the hierarchies and customs of the societies that he encounters he also makes observations that are intended to serve European commercial or scientific interests, and future exploration or potentially even military expansion. In La Duchesse de Langeais the splitting is chronological: there is a sudden inversion of roles, as abrupt as the achronological narrative order itself. At one moment Montriveau is an explorer in the desert of the aristocratic heart, struggling to reach a perhaps impossible oasis; at the next he becomes a powerful figure, part of a secret homosocial brotherhood, while Antoinette herself is in love and vulnerable. In a narrative chiasmus that she herself expresses, she is struggling not towards the oasis but, despairingly, into the desert: “moi, je me traîne de l'oasis au désert, et vous m'êtes un guide sans pitié" (5: 1026). At the novella's end, in the same figure of chiasmus, only her lifeless body is carried away from the island convent by Montriveau, whereas his living body had been carried into the oasis in the arms of his mighty guide.

\section{Failed cognitive mapping}


If Africa is a metaphor for the deserts of the human heart, it is initially the Duchess's heart that resists exploration. Montriveau experiences the obstacles she capriciously places before him as if they were "des voiles [...] qu'il fallait lever un à un" (5: 979). This Romantic imagery of unveiling is associated with the Orient, notably with the statue of Isis unveiled by a young traveller in Egypt, thirsty for knowledge, in Friedrich von Schiller's influential 1795 poem "The Veiled Image at Sais" ("Das verschleierte Bild zu Saïs"). ${ }^{23}$ The poem ends with the death of the rash seeker of knowledge. Both Montriveau's African exploration and his venture into the mysterious dark heart of the aristocratic faubourg end not in death, but less dramatically in failure. He, like Caillié, survives his voyage (just); but the information brought back by both men is at best sparse and fragmentary.

That the "mapping" of Africa should be represented as a failed project in the 1830s is no surprise. European explorers were attempting to sketch out routes into the interior of Africa that would later facilitate political and economic expansion, but it would be two generations before the "scramble for Africa" that began after the Berlin conference of 1884 . In any case, the African interior was still connoted as "dark" and inaccessible to rational knowledge at the time of Joseph Conrad's Heart of Darkness (1899). As Christopher L. Miller has argued, Africanist discourse projects Africa as a dark continent, and Africanism as "an unhappy Orientalism, a discourse of desire unfulfilled and unfulfillable" (23). So Balzac's choice of the exploration of Africa as the vehicle of an extended metaphor does not suggest a safely established map or a securely tamed or colonizable Africa: on the contrary, the attempt to chart the desert is a perilous project leading to epistemological breakdown.

The experiences of Caillé and Montriveau both end with this epistemological failure. Although Caillié did manage to publish his travel narrative, both men in fact fail to bring back proper scientific accounts that would successfully map, classify and organise Africa into a territory subject to scientific knowledge, or French trade ("imposer aux populations 
lointaines le tribut de notre industrie,” Caillié 1: viii). Travelling in disguise, Caillié can only take "des notes fugitives, très-laconiques [sic], écrites en tremblant et pour ainsi dire en courant," and even these notes are half effaced by the time he returns. He is frequently obliged to rely on memory alone to write his book, and he is apologetic about this as well as his own less than accomplished writing style (1: iv-vi). Montriveau's experience sinks one step further into oblivion, since his memory itself fails due to the traumatic nature of his experiences. Such are his sufferings that he has only "d'informes souvenirs. Les immenses sacrifices de son voyage, l'étude des dialectes de l'Afrique, ses découvertes et ses observations, tout fut perdu." (5: 942). He then fails to realize that he has reached his goal in his exploration into the heart of the faubourg St-Germain: he does make himself loved by the Duchess, but is never united with her, physically or emotionally. In the end the Duchess is reduced to nothing: "c'était une femme, maintenant ce n'est rien," as Ronquerolles puts it before they discard her corpse in the sea. Montriveau can only agree, though he rephrases what his beloved ideal Lady has been reduced to: "ce n'est plus qu'un poème" (5: 1037, my emphasis). If she, like her pure-blood, Ancien-Régime aristocracy, is now merely a poem, Montriveau must turn his back on them, as well as renouncing his earlier life as an explorer, "un homme dont la vie n'avait été [...] qu'une suite de poésies en action" (5: 908, my emphasis). His future will lie not in Romantic poetry or the poetic exploration of nighimpossible oases or aristocratic ideals, but in the prosaic nouveau régime of the bourgeois monarchy.

In his study of the novella, Peter Brooks discusses Antoinette's long delaying of Montriveau's sexual desires as a strip-tease. He compares the process of getting to know the Duchess's body metonymically, piece by piece, to the desire of the voyeuristic novelist, or the bourgeois in aristocratic society, to remove veils and penetrate houses and façades. Sexual desire stands in for desire for knowledge in what he calls "epistemophilia." Failure to 
reach Montriveau's sexual goal thus echoes the double failure of knowledge that Balzac recounts. Cognitive mapping, in other words, is presented not as a neat solution, but as a problematic or near-impossible task. This recalls Graham Huggan's discussion of the dual nature of cartography in the service of imperialism, in which he points out the tension between the map as a controlling coherent structure or as a series of analogies, and notes "blind spots" on maps that deconstruct their supposed universalism (126-27). A map is an attempt at sorting the world into ordered information in a rational and spatially imagined form. The failure of the double project of exploration in Balzac's novella suggests that this goal is far from being easily achieved. If Montriveau is an avatar of Balzac, then his double failure suggests the self-consciously imperfect nature of Balzac's own project of cognitive mapping. Jameson, as we recall, asserts that in modernism the attempted cognitive mapping of the emerging global system is marked by failure. Balzac's Comédie humaine, with its vast geographical, social and historical mapping of the French system, is already shot through with awareness of the failure or incompletion of a mapping project that would extend to a global vision.

University of Oxford (Christ Church)

\section{Works Cited}

Balzac, Honoré de. La Comédie humaine. Edited by Pierre-Georges Castex et al., Gallimard, “Bibliothèque de la Pléiade," 1976-81. 12 vols. Particularly La Duchesse de Langeais, ed. by Rose Fortassier, in vol. 5.

Baron, Anne-Marie. "La Duchesse de Langeais ou la coquetterie du narrateur." Le Courrier balzacien, vol. 34, 1989, pp. 5-17. 
---. “Les ‘Égyptiens' et leur traversée du desert.” Balzac voyageur: parcours, déplacements, mutations, edited by Nicole Mozet and Paule Petitier, Publications de l'Université François Rabelais, 2004, pp. 39-54.

Bell, Dorian. "Balzac's Algeria: Realism and the Colonial." Nineteenth-Century French Studies, vol. 40, no. 1-2, Fall-Winter 2011-12, pp. 35-56.

Bray, Patrick. The Novel Map: Space and Subjectivity in Nineteenth-Century French Fiction, Northwestern UP, 2013.

Brooks, Peter. "Balzac: Epistemophilia and the Collapse of the Restoration." Yale French Studies, vol. 101, 2002, pp. 119-31.

---. Body Work: Objects of Desire in Modern Narrative. Harvard UP, 1993.

Caillié, René. Journal d'un voyage à Temboctou et à Jenné, dans l'Afrique centrale, précédé d'observations faites chez les Maures Braknas, les Nalous et d'autres peuples; pendant les années 1824, 1825, 1826, 1827, 1828 par René Caillié. Avec une carte itinéraire, et des remarques géographiques, par M. Jomard, membre de Paris: Imprimerie royale, 1830. Citron, Pierre. "Le rêve asiatique de Balzac." L'Année balzacienne, 1968, pp. 303-36. Conley, Tom. The Self-Made Map: Cartographic Writing in Early-Modern France. U of Minnesota P, 1996.

Déruelle, Aude. “'L’Égypte, c'est tout sables': Balzac et le récit de voyage.” Voyager en France au temps du romantisme: poétique, esthétique, idéologie, edited by Alain Guyot and Chantal Massol, ELLUG, 2003, pp. 325-41.

Fiorentino, Francesco. “'La Duchesse de Langeais' et la critique de la passion romantique.” L'Année balzacienne, vol. 1, 2000, pp. 223-29.

Gerwin, Elisabeth. "Un enlèvement peut en cacher un autre: Kidnapping the Past in $L a$ Duchesse de Langeais." Nineteenth-Century French Studies, vol. 41, no. 1-2, Fall-Winter 2012-13, pp. 25-47. 
Guyon, Bernard. La Pensée politique et sociale de Balzac. Armand Colin, 1947.

Huggan, Graham. "Decolonizing the Map: Post-Colonialism, Post-Structuralism and the Cartographic Connection." Past the Last Post: Theorizing Post-Colonialism and PostModernism, edited by Ian Adam and Helen Tiffin, Harvester and Wheatsheaf, 1991, pp. 2538.

Jameson, Fredric. The Antinomies of Realism. London: Verso, 2013.

---. "Cognitive Mapping.” Marxism and the Interpretation of Culture, edited by Cary Nelson and Lawrence Grossberg, Macmillan, 1988, pp. 347-57.

Mileham, James W. “Desert, Desire, Dezesperance: Space and Play in Balzac's La Duchesse de Langeais." Nineteenth-Century French Studies, vol. 31, no. 3-4, Spring-Summer 2003, pp. 210-25.

Miller, Christopher L. Blank Darkness: Africanist Discourse in French. U of Chicago P, 1985.

Moretti, Franco. Atlas of the European Novel 1800-1900. Verso, 1998.

Pratt, Mary Louise. Imperial Eyes: Travel Writing and Transculturation. Routledge, 1992.

Quella-Villéger, Alain. René Caillié l'Africain: une vie d'explorateur (1799-1838). Aubéron, 2012.

Rogers, Nathalie Buchet. “De 93 à L'Histoire des Treize: La Terreur de (Marie)-Antoinette de Langeais." Revue d'histoire littéraire de la France, vol. 101, no. 1, 2001, pp. 51-69. Roy-Reverzy, Eléonore. “'La Duchesse de Langeais': un romanesque de la séparation?” L’Année balzacienne, vol. 16, 1995, pp. 63-81.

Said, Edward. Culture and Imperialism. Chatto and Windus, 1993.

Seillan, Jean-Marie. Aux sources du roman colonial: l'Afrique à la fin du XIX siècle. Karthala, 2006. 
Thompson, C.W. French Romantic Travel Writing: Chateaubriand to Nerval. Oxford UP, 2012.

Tilby, Michael. “La Duchesse de Langeais en livraisons: Balzac et L'Écho de la jeune France." L'Année balzacienne, vol. 9, 2008, pp. 259-82.

${ }^{1}$ As Dorian Bell has shown, the geography of the Comédie, striking in its "cartographic precision," nevertheless leaves the colonial space of Algeria-and beyond it the rest of Africa-as vague as a "phantom limb" (35).

${ }^{2}$ The importance of Balzac's African micro-narrative is often played down even by studies that focus on Africa. Seillan, for example, merely observes - correctly-that Balzac gives Montriveau “un véritable passé d'explorateur [...] mais il s'en tient à un bref sommaire sans songer à tirer l'intrigue d'un roman entier de ce scénario superbe" (10).

${ }^{3}$ See Fredric Jameson, “Cognitive Mapping” 353, 356. He first uses the term in 1981 in The Political Unconscious, adopting it from a sub-discipline inspired by Kevin Lynch's book The Image of the City (1960).

${ }^{4}$ For Citron, Africa in La Duchesse de Langeais is a distant "reflet [des] obsessions de volupté asiatique," and this is "une simple coloration esthétique" that is not of any real importance to the tale (319). Africa is also the Orient for Baron ("La Duchesse" 11).

${ }^{5}$ See Gerwin 28-30 and 33-35. Her argument is that Montriveau's experience of enslavement and escape in Africa foreshadows his later kidnapping of the Duchess.

${ }^{6}$ Fiorentino 224. For an alternative reading of space in the Duchesse de Langeais in terms of games and ritual initiations — an approach that has the disadvantage of being apolitical — see Mileham.

${ }^{7}$ See Roy-Reverzy. She does not really discuss the African experiences, although they would fit in well with her focus on separation. 
${ }^{8}$ Hugo, Preface to Les Orientales, 1829; his celebration of Spain's Moorish heritage takes the form of a poetic description of a medieval city. Hugo's landmark volume of poetry was published only four years before Balzac's novella. Balzac makes striking use of Andalusian (and African) themes again much later, in Mémoires de deux jeunes mariées (1842). While one of the brides, Renée, is reborn through motherhood and a sensible marriage in the provinces, the other, the aristocratic Louise, pursues absolute love in Paris. She marries an energetically masculine and passionate Spanish aristocrat, the "Abencérage" or "Maure" Felipe but her love thrives on humiliating him and in the end destroys him (in contrast, in $L a$ Duchesse de Langeais, Montriveau resists, and abducts his aristocratic prize, asserting his masculinity). Louise embarks on a second passionate and irrational marriage which seems to Renée as dangerous as a voyage into the "centre mystérieux de 1'Afrique" (1:371).

${ }^{9}$ For the history of the first (interrupted) publication of 1833, see Tilby; also Guyon 624-26. The full text was published in 1834 , with a second edition where the novella appears under the title La Duchesse de Langeais, alongside Ferragus, in 1839. In 1843 the third edition appeared, with these two alongside La Fille aux yeux d'or as part of the Histoire des Treize, integrated into the Comédie humaine.

${ }^{10}$ See for example Baron, "Les ‘Égyptiens"” 39 and 42-43.

${ }^{11}$ The prize was won by Tennyson for "Timbuctoo," in which he drew parallels between the legendary African city and the mythical Atlantis or Eldorado. The poem celebrates the glory of the imagination, and ends with the failure of dreams when confronted with the reality of a village of huts surrounded by mud walls.

${ }^{12}$ Caillié's Journal was re-edited in 1961 (Club des Éditeurs, 1 vol.), 1965 (Éditions Anthropos, 3 vols) and 1979 (Maspero/La Découverte, 2 vols), but my references are to the 1830 edition, now available online through Gallica. 
${ }^{13}$ The late eighteenth-century travels of the Scot Mungo Park in Africa may also have influenced Balzac's Montriveau. Among other sources, Fortassier also refers the reader to Napoleon's Egyptian expedition, the Description de l'Égypte and Champollion (though the latter was famous for his decipherment of hieroglyphs rather than his travels). See her introduction, Balzac 5: 761 and 942n1.

${ }^{14}$ Quella-Villéger 153, 156; more generally, see 141-60 for Caillié's Parisian experiences.

${ }^{15}$ On the "anti-conquest" strategy of representation see Pratt 7; on the influence of the sentimental mode see 75 and following.

${ }^{16}$ Pratt makes the point about Rousseau being a model for the travel narrative. Patrick Bray stresses the influence of Rousseau's autobiographical works in the nineteenth century: writing in the first person contributed to the newly unstable position of the self $(7-8,11-12)$. ${ }^{17}$ For one of many examples of Caillié being humiliated, and depending on charity for water and food, see 3: 15-16. See also Quella-Villéger 111.

${ }^{18}$ Fortassier suggests the influence of Caillié's account on Montriveau's experience in this episode, though it is worth pointing out that Caillié is carried in the arms of a kindly stranger whereas Montriveau is carried by his guide (5: $946 \mathrm{n} 1)$.

${ }^{19}$ An example of such imagery is used as the cover of Pratt's volume: "La montée de l'agonie," by D. Maillet, in Edouard André, "Voyage dans l'Amérique Equinoxiale," Le Tour du Monde, Paris 1879.

${ }^{20}$ 5: 981, my emphasis. Descriptions of Paris as a desert abound since Chateaubriand's René (1802), not least in the Comédie humaine. In La Peau de chagrin Raphaël is "seul au milieu du plus affreux désert, un désert pavé, un désert animé, pensant, vivant, où tout vous est bien plus qu'ennemi, indifférent!” (10: 133). The homosocial company and support provided by the Treize is the fantasy of a palliative to this isolation and vulnerability. 
${ }^{21}$ Caillié 2: 347-50. He advises future explorers that the best way to cross the Sahara is to travel "très-simplement [sic], sans aucune espèce de luxe, mais adopter extérieurement le culte de Mahomet, se faire passer dans le pays pour Arabe." (2: 352).

${ }^{22}$ See also Pratt 85.

${ }^{23}$ Balzac refers to this specific poem in Béatrix (2: 696), published in 1839 , when he also corrected the second edition of La Duchesse de Langeais. He regarded Schiller as one of the key writers of modern (Romantic) literature (see for example Modeste Mignon, 1: 497 and $505)$. 